\title{
Impact of nano-chelated micronutrients and biological fertilizers on growth performance and grain yield of maize under deficit irrigation condition
}

\section{Mohsen Janmohammadi ${ }^{1 *}$,}

Azra Navid ${ }^{1}$,

Asghar Ebadi Segherloo²,

Naser Sabaghnia ${ }^{1}$

${ }^{1}$ Department of Agronomy

and Plant Breeding,

Agriculture College,

University of Maragheh, Iran

${ }^{2}$ Moghan College of Agriculture and Natural Resources,

University of Mohaghegh Ardabili, Ardabil, Iran
Sustainable crop production is required for the semi-arid areas, and it will be achieved by the wise use of several production inputs which must be tailored to the unique conditions of each district. Effective nutrient management and irrigation are just two parts of the crop production puzzle. It seems that nano-fertilizers may have high potential for achieving sustainable crop production. A field experiment was carried out to investigate the effect of adding different fertilizers on maize (S.C 704 Hybrid) growth under various irrigation regimes in Moghan, northwest of Iran. The experiment included three irrigation levels (up to $\sim 100, \sim 50$, and $\sim 25 \%$ field capacity) which were applied from the beginning of the reproductive period. During the vegetative period, all plants were fully irrigated. Fertilizer treatments included control (no-fertilizer application), $\mathrm{N}$ biofertilizer, $\mathrm{P}$ biofertilizer, nano-chelated $\mathrm{B}$, nano-chelated $\mathrm{Zn}$, complete nanofertilizer, and bulk NPK fertilizer. Investigation of morphophysiological traits such as leaf area, ear length, ear diameter, relative water content, and chlorophyll content revealed that application of complete micronutrients, bulk NPK, and nano-chelated Zn significantly improved these traits over the control. A similar status was recorded for grain yield and yield components. Results indicated that although irrigation up to $\sim 25 \%$ of field capacity (FC) reduced the grain yield compared to the control, there was not observed any significant difference between normal irrigation and $\sim 50 \%$ FC. The best plant performance was recorded for plants grown by complete nanofertilizer under optimum or $\sim 50 \%$ FC. Deficient irrigation up to $\sim 50 \%$ FC could be assigned as an appropriate water management strategy in semi-arid regions to minimize water losses through evaporation and achieve higher water use efficiency. In conclusion, a combination of precision deficient irrigation and application of nanofertilizers play a critical role for enhancing the efficient use of water and improving the productivity of maize production systems in Mediterranean semi-arid regions.

Key words: biofertilizer, nano-chelated micronutrients, nano-fertilizers, watering strategy, yield components 


\section{INTRODUCTION}

Maize (Zea mays L.) is an important cereal crop, and it has a special position in cash crop farming systems. Maize ranks third after wheat and rice in the world and is produced throughout Iran under diverse environments. In Iran, maize is cultivated in an area of 425 thousand ha giving annual production of 2,450,000 tons with the average yield of $5,976 \mathrm{~kg} \mathrm{ha}^{-1}$ (FAO, 2013). The bulk of maize produced is used for livestock feed, and its consumption is significantly increasing.

Mediterranean semi-arid zones are characterized by low erratic rainfall, and in these areas water shortage is the most severe restriction for improvement of crop productivity. Although the "green revolution" could notably increase cereal-grains production through applying the modern agricultural technologies, including irrigation and heavy doses of chemical fertilizer in some regions, the arid and semi-arid areas have not greatly benefited from the "green revolution" as much as regions that have sufficient precipitation. Although it appears that primary plant production in drier agro-ecological zones, such as in West Asia and North Africa (WANA) with a Mediterranean-type climate is usually constrained by water limitation, but in fact nutrients also frequently limit production (Hoekstra, Shachak, 1999; Ryan et al., 2012). It seems that available soil moisture has a significant influence on nutrient use efficiency and ultimately determine crop yield. In WANA region, the loss of organic matter and low fertility are of great concern. This is partly due to low biomass production and high rates of organic matter decomposition. Consequently, nutrient deficiencies or nutrient imbalance has been reported for a long period of time as a result of decline in soil organic carbon status in semiarid regions of WANA (Sahrawat, Wani, 2013).

During the last decades, application of the fertilizers has increased in WANA regions. Given the increased fertilizer consumption, nutrient management is a fundamental concern from the economic perspective (Golzarfar et al., 2012). However, currently there is a range of options available for fertilizer management. The utilization of biofertilizers has become very important in agriculture division for their potential role in improving soil fertility, plant tolerance and crop productivity (Bhardwaj et al., 2014). Biofertilizers refer to preparations containing living cells or effectual strains of symbiotic and non-symbiotic microorganisms. These are beneficial bacterial or fungal inoculants that improve the uptake of nutrients by crop roots via their interactions in the rhizosphere when utilized through seed or soil. Biofertilizers can increase plant growth by various mechanisms such as fixation of atmospheric nitrogen, production of siderophores that chelate metal elements and make them available to the plant root, solubilization of minerals such as phosphorus, and synthesis of phytohormones (Glick, 1995). Nitrogen and phosphorus are the two essential nutrients for maize growth and development; therefore, inoculation of $\mathrm{N}$ and $\mathrm{P}$ biofertilizers could strongly improve the plant performance (Janmohammadi et al., 2012). It has been recognized that chemical fertilizers may have some problems such as leaching out, polluting water basins, destroying microorganisms and friendly insects, making the crop more susceptible to the attack of diseases, reducing the soil fertility and thus causing irreparable damage to the overall system; however, it seems that biofertilizer application can overcome these problems (Chen, 2006).

However, most farmers in semi-arid regions apply only those fertilizers that supply macronutrients, and also due to the high alkalinity of the soils, low plant availability of micronutrients are prominent (Ryan et al., 2012). Although much lower levels of micronutrients are needed to satisfy yield and quality, they play vital roles in the development of plants, and the correct balance of these trace elements is essential (Hänsch, Mendel, 2009; Marschner, 2012). However, up to now chemical fertilizers have been the main source of supplying the micronutrients, while recently the tendency to use new generation of fertilizers which are based on nanotechnology significantly increased (DeRosa et al., 2010; Naderi, Danesh-Shahraki, 2013). 
Nanotechnological discoveries could open up novel applications in the field of biotechnology and agriculture. Nanofertilizers are innovative agricultural inputs which are aimed to release nutrients into the soil gradually and in a controlled way, thus avoiding environmental damages and improving the crop growth and productivity (Sekhon, 2014). Nano active ingredients, which are $1-100 \mathrm{~nm}$ in diameter, have a large specific surface area that can result in an acceptable reactivity, and this feature increases effective absorption of nutritional elements and essential compounds for plant growth and plant metabolism (Morteza et al., 2013). In nanofertilizers, nutrients can be encapsulated by nanomaterials, coated with a thin protective film, or delivered as emulsions or nanoparticles (DeRosa et al., 2010). In a new type of nanofertilizers, the nutrients can be released in response to environmental factors. It seems that nanofertilizers could be able to release nutritional elements in a controlled manner (slowly or quickly) in reaction to different environmental fluctuations such as temperature, moisture and soil acidity, so it can enhance plant growth more effectively compared with traditional fertilizers (Naderi, Danesh-Shahraki, 2013). However, in traditional type most of the utilized fertilizers are rendered unavailable to crops due to various reasons, such as hydrolysis, leaching, decomposition and degradation by photolysis. Consequently, it is essential to reduce nutrient losses in fertilization and to increase nutrient use efficiency through the application of "smart nanofertilizers" (Siddiqui et al., 2015). It appears that nanofertilizers provide the nanoscale or nanostructured nutrients in a controlled-release and lead to an increased efficiency of the nutrients, diminish the toxicity of the soil, improve nutrient use efficiency and decrease costs of environmental protection (Naderi, Danesh-Shahraki, 2013; Sekhon, 2014).

However, in semi-arid regions, where water resources are restrictive, the main challenge for the future decades will be the task of meeting food requirements with less water. In the context of enhancing water productivity, there is a growing interest in deficit irrigation, a watering strategy whereby water supply is reduced below maximum levels and mild stress is allowed with minimal effects on yield (Geerts, Raes, 2009). This method can be more profitable for a farmer to maximize crop water productivity instead of maximizing the harvest per unit land (Fereres, Soriano, 2007). Despite the plenty of information available on foliar application of some nanoparticles on plant growth and development, there is no sufficient information about efficiency of nanofertilizers under water scarcity condition. Therefore, the present study was carried out to evaluate the impact of biofertilizers and nanofertilizers under full and deficit irrigation on growth, yield and yield components of maize in the northwest of Iran.

\section{MATERIALS AND METHODS}

Field experiments were carried out at the Research Farm of the Moghan College of Agriculture and Natural Resources, Parsabad, Ardabil, Iran, during the growing season of 2014. The field was located at $46^{\circ} 46^{\prime}$ east longitude and $39^{\circ} 36^{\prime}$ north latitude, at an altitude of 32 meters above sea level. Based on Koppen's classification, this region has a semi-arid temperate climate. Moghan has warm and humid summers and temperate winters with dry winds and a short freezing period. Top $0-30 \mathrm{~cm}$ soil samples were randomly collected from field and analyzed for physicochemical properties. The soil type was clay loam, pH 7.22 and EC $2.35 \mathrm{dS} . \mathrm{m}^{-1}$, organic matter $0.85 \%$, potassium $306.4 \mathrm{mg} \mathrm{kg}^{-1}$, phosphorous $15.8 \mathrm{mg} \mathrm{kg}^{-1}$. Moghan is located in the plain of the Aras River and its level areas with deep, well-drained soils, and cropping in this region is most reliable. The mean annual temperature was $15{ }^{\circ} \mathrm{C}$ while the mean maximum and minimum temperatures were 31.4 and $1.4^{\circ} \mathrm{C}$, respectively. The mean temperature during the growth season was $21^{\circ} \mathrm{C}$ and average annual rainfall was about $335 \mathrm{~mm}$. The total rainfall during the growing season was 124 $\mathrm{mm}$. The trial was conducted in a split-split block design with three replications. The treatments were composed of deficit irrigation in 
three levels $(100,50$, and $25 \%$ soil water content in field capacity (FC) level) during initiation of reproductive growth until the maturity stage as the main plot and fertilizer application in seven levels as subplots. At the mentioned area, the clay loamy soil has sufficient depth (more than 1 meter) and field capacity was at 33.4 percent and wilting point at 16.0 percent by volume for the surface to the $100-\mathrm{cm}$ soil layer. Field capacity and the permanent wilting point determined by the Time Domain Reflectometry method. Irrigation was applied when the tap half the root zone depth approached $50 \%$ depletion level.

Seeds of a single cross 704 hybrid were obtained from the Agricultural Engineering Research Center of Parsabad Moghan. Uniform maize seeds were hand sown on 27 April at $5 \mathrm{~cm}$ depth of soil. Seeds were hand sown, 3 seeds per hill, and then at the 3-leaf stage, hills were thinned so that only one plant per hill was left. Each experimental plot area was $25 \mathrm{~m}^{2}$ $(5 \times 5 \mathrm{~m})$ with $0.65 \mathrm{~m}$ spacing between rows and $0.2 \mathrm{~m}$ spacing between plants. Soil was tilled by mouldboard ploughs during the $\mathrm{Au}$ gust 2013, and seedbed preparation was carried out by disc plough, disks, leveler and furrower during April 2014. A two-meter gap was provided between the main plots to avoid the effect of irrigation treatment.

Fertility treatments consisted of control (nofertilizer application), nitrogen biofertilizer (contained Azotobacter vinelandii strain O4), phosphorous biofertilizer (contained phosphatesolubilizing bacteria, Pantoea agglomerans strain
P5, and Pseudomonas putida strain P13), nanochelated boron, nano-chelated zinc, complete nanofertilizer, and chemical bulk NPK. Biofertilizers were applied as seed inoculation just before planting. Chemical bulk NPK consisted of $180 \mathrm{~kg} \mathrm{~N} \mathrm{ha}^{-1}$ in the form of urea, $100 \mathrm{~kg} \mathrm{P} \mathrm{ha}^{-1}$ in the form of super phosphate, and $50 \mathrm{~kg} \mathrm{~K} \mathrm{ha}^{-1}$ in the form of potassium sulfate. Half of $\mathrm{N}$ and all of $\mathrm{P}$ and $\mathrm{K}$ were applied before sowing (incorporated by disk). The remaining $\mathrm{N}$ was applied as a top dressing one month after sowing. Nano-chelated fertilizers were obtained from the Fanavar Sepehr Parmis Company, Iran. Because of the calcareous nature of the region, soil micronutrients nanofertilizers were applied as foliar spry. Micronutrients nanofertilizers were applied three times at the concentration of 2,000 ppm during the 9-leaf stage (BBCHscale $=19$ ), stem elongation (two nodes detectable; $\mathrm{BBCH}$-scale $=32$ ), heading (beginning of tassel emergence; $\mathrm{BBCH}$-scale $=51$ ). Nano-fertilizers contained nanparticles of zinc oxide, boric acid or combination of absorbable forms of key micronutrient elements ( $\mathrm{Fe}, \mathrm{Cu}, \mathrm{Zn}, \mathrm{B}, \mathrm{Mn}$ ). Synthesized nanoparticles had been characterized morphologically by transmission electron microscopy (Fig. 1). Two hand weedings were carried out at 20 and 40 days after the sowing date. All necessary cultural practices and plant protection measures were followed uniformly for all the plots during the entire period of experimentation. Relative water content (RWC) was measured in leaves adjusted to ear at the beginning of grain development stage $(\mathrm{BBCH}-$ scale $=71$ ) according to the following equation
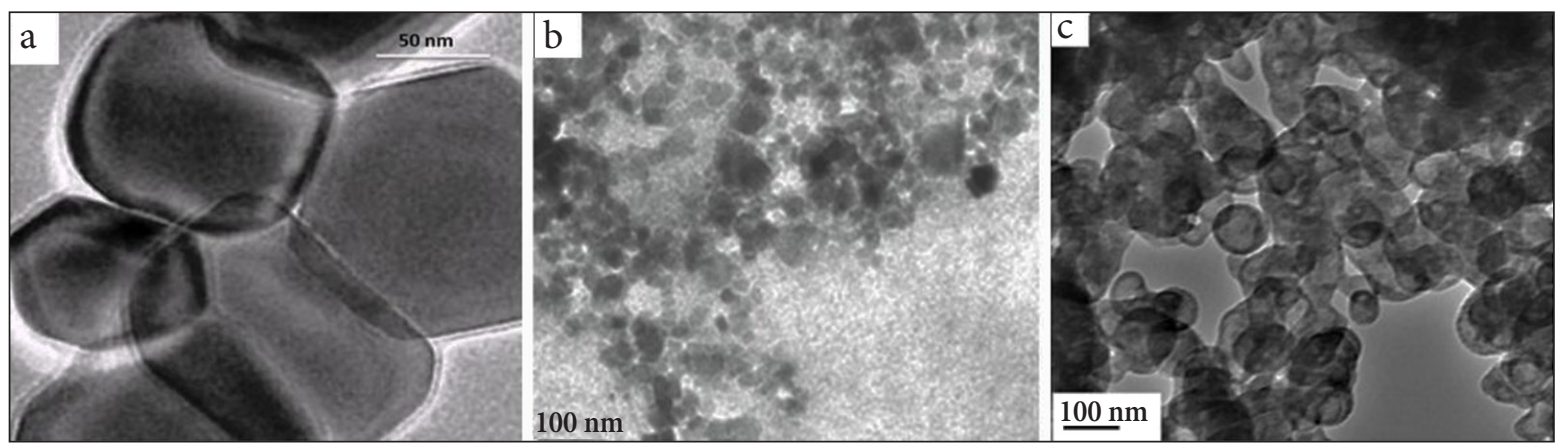

Fig. 1. Transmission electron microscopy (TEM) micrograph of synthesized boric acid $\left(\mathrm{H}_{3} \mathrm{BO}_{3}\right)$ nanoparticles (a), nano zinc oxide (b), and iron oxide nanoparticles (c) 
$\left[((\mathrm{FW}-\mathrm{DW}) /(\mathrm{TW}-\mathrm{DW}))^{*} 100\right]$, where FW, TW, and DW are fresh weight $(\mathrm{g})$, turgid weight $(\mathrm{g})$, and dry weight (g), respectively. Chlorophyll content was measured on ten leaves of a plant at each plot, using a portable chlorophyll meter (SPAD) at the beginning of grain development stage. The central two rows from each plot were harvested at maturity, and different agronomic traits and yield components were measured in each plot. The parameters measured included: plant height, length of leaf adjacent to ear, hundred kernel grain weight, kernel number, number of the kernels per row, number of the rows per ear, cob diameter, ear diameter, ear length, stem diameter, leaf area per plant $\left(\mathrm{cm}^{2}\right)$, biological yield, straw yield, seed yield, and harvest index. Protein percent and oil percent of seeds were measured using a near- infrared seed analyzer (Zeltex). The data were tested for skewness and kurtosis normality of distribution by SPSS Statistics 17.0 (SPSS Inc., Chicago, IL, USA). The experimental data were statistically analyzed for variance using the SPSS and MINITAB version 14 (Minitab Inc., Harrisburg, PA, USA). Differences in character means were also measured using the Least Significant Difference (LSD).

\section{RESULTS}

Analysis variance showed that irrigation significantly affected the plant height, while the fertilizer treatment effect was not statistically significant. Drastic reduction in the volume of irrigation (up to $25 \%$ of field capacity) reduced the plant height about by $13 \%$ compared to fully

Table 1. Effect of irrigation levels and different fertilizers on some morphological traits of maize (Zea mays L.)

\begin{tabular}{|c|c|c|c|c|c|c|c|c|c|c|}
\hline Fertilizers (F) & PH & LLE & $\mathrm{CD}$ & ED & $\mathrm{EL}$ & STD & LA & RWC & $\mathrm{CHL}$ & NRE \\
\hline Control & $187.33^{\mathrm{a}}$ & $73.86^{\mathrm{a}}$ & $2.17^{\mathrm{b}}$ & $4.07^{c}$ & $17.84^{\mathrm{b}}$ & $2.77^{c}$ & $2653.80^{\mathrm{b}}$ & $79.51^{\mathrm{ab}}$ & $35.81^{c}$ & $15.37^{\mathrm{a}}$ \\
\hline $\mathrm{N}$ biofertilizer & $191.23^{\mathrm{a}}$ & $73.61^{a}$ & $2.23^{\mathrm{ab}}$ & $4.23^{\mathrm{abc}}$ & $18.84^{\mathrm{ab}}$ & $2.97^{\mathrm{bc}}$ & $2826.98^{\mathrm{ab}}$ & $76.00^{\mathrm{b}}$ & $39.77^{\mathrm{bc}}$ & $15.82^{\mathrm{a}}$ \\
\hline P biofertilizer & $193.41^{\mathrm{a}}$ & $72.04^{\mathrm{a}}$ & $2.25^{\mathrm{ab}}$ & $4.26^{\mathrm{abc}}$ & $19.84^{\mathrm{ab}}$ & $2.90^{c}$ & $2891.53^{\mathrm{a}}$ & $74.96^{\mathrm{b}}$ & $36.40^{c}$ & $15.64^{\mathrm{a}}$ \\
\hline Nano-chelated B & $193.91^{\mathrm{a}}$ & $77.85^{\mathrm{a}}$ & $2.23^{\mathrm{ab}}$ & $4.18^{\mathrm{bc}}$ & $20.07^{\mathrm{ab}}$ & $2.97^{\mathrm{bc}}$ & $2771.45^{\mathrm{ab}}$ & $79.67^{\mathrm{ab}}$ & $39.47^{c}$ & $15.64^{\mathrm{a}}$ \\
\hline $\begin{array}{c}\text { Nano-chelated } \\
\text { Zn } \\
\end{array}$ & $196.86^{\mathrm{a}}$ & $76.00^{\mathrm{a}}$ & $2.31^{\mathrm{ab}}$ & $4.38^{\mathrm{ab}}$ & $21.51^{\mathrm{ab}}$ & $3.19^{\mathrm{ab}}$ & $2849.56^{\mathrm{a}}$ & $79.50^{\mathrm{ab}}$ & $45.61^{\mathrm{ab}}$ & $15.91^{\mathrm{a}}$ \\
\hline $\begin{array}{c}\text { Complete na- } \\
\text { nofertilizer }\end{array}$ & $190.35^{\mathrm{a}}$ & $78.33^{a}$ & $2.31^{\mathrm{ab}}$ & $4.50^{\mathrm{a}}$ & $22.88^{\mathrm{a}}$ & $3.32^{\mathrm{a}}$ & $2874.77^{\mathrm{a}}$ & $84.45^{\mathrm{a}}$ & $47.83^{\mathrm{a}}$ & $15.90^{\mathrm{a}}$ \\
\hline Chemical NPK & $194.92^{\mathrm{a}}$ & $75.86^{\mathrm{a}}$ & $2.22^{\mathrm{ab}}$ & $4.35^{\mathrm{ab}}$ & $22.03^{\mathrm{a}}$ & $2.97^{b c}$ & $2929.58^{\mathrm{a}}$ & $75.96^{\mathrm{b}}$ & $47.74^{\mathrm{a}}$ & $15.60^{\mathrm{a}}$ \\
\hline \multicolumn{11}{|c|}{ Irrigation (I) } \\
\hline $100 \% \mathrm{FC}$ & $204.36^{\mathrm{a}}$ & $79.20^{\mathrm{a}}$ & $2.28^{\mathrm{a}}$ & $4.58^{\mathrm{a}}$ & $22.23^{\mathrm{a}}$ & $3.17^{\mathrm{a}}$ & $3088.14^{\mathrm{a}}$ & $82.78^{\mathrm{a}}$ & $49.25^{\mathrm{a}}$ & $15.75^{\mathrm{a}}$ \\
\hline $50 \% \mathrm{FC}$ & $194.40^{\mathrm{ab}}$ & $77.34^{\mathrm{ab}}$ & $2.24^{\mathrm{a}}$ & $4.20^{\mathrm{b}}$ & $22.20^{\mathrm{a}}$ & $3.10^{\mathrm{a}}$ & $2751.19^{b}$ & $80.46^{\mathrm{a}}$ & $39.98^{\mathrm{b}}$ & $15.77^{\mathrm{a}}$ \\
\hline $25 \% \mathrm{FC}$ & $178.81^{\mathrm{b}}$ & $69.56^{\mathrm{b}}$ & $2.22^{\mathrm{a}}$ & $4.07^{\mathrm{b}}$ & $16.78^{\mathrm{b}}$ & $2.77^{\mathrm{b}}$ & $2645.39^{\mathrm{b}}$ & $72.50^{\mathrm{b}}$ & $36.18^{\mathrm{b}}$ & $15.58^{\mathrm{a}}$ \\
\hline LSD at $p \leq 0.05$ & 18.81 & 7.81 & 0.104 & 0.281 & 4.18 & 0.028 & 184.21 & 6.98 & 5.89 & 0.647 \\
\hline \multicolumn{11}{|c|}{ Significance level } \\
\hline $\mathrm{F}$ & NS & NS & $* *$ & * & $* *$ & ** & $* *$ & $* *$ & $* *$ & NS \\
\hline I & $*$ & * & NS & NS & $* *$ & $* *$ & $* *$ & $* *$ & $* *$ & NS \\
\hline $\mathrm{F} \times \mathrm{I}$ & NS & NS & NS & NS & NS & * & * & NS & $\star$ & NS \\
\hline $\mathrm{CV} \%$ & 5.92 & 10.65 & 2.71 & 3.94 & 12.41 & 5.57 & 13.95 & 5.39 & 8.55 & 6.50 \\
\hline
\end{tabular}

$\mathrm{PH}=$ plant height $(\mathrm{cm}), \mathrm{LLE}=$ leaf length adjacent to ear $(\mathrm{cm}), \mathrm{CD}=$ cob diameter $(\mathrm{cm}), \mathrm{ED}=$ ear diameter, EL = ear length $(\mathrm{cm}), \mathrm{STD}=$ stem diameter, LA = leaf area per plant $\left(\mathrm{cm}^{2}\right)$, RWC = relative water content $(\%), \mathrm{CHL}=$ chlorophyll content (SPAD unit), $\mathrm{NRE}=$ number of the rows per ear. Mean values of the same category followed by different letters are significant at $p \leq 0.05$ level. 
irrigated plants (Table 1). A similar trend was observed for the length of leaf adjacent to the ear, so the leaves length of the plants grown under $25 \% \mathrm{FC}$ was by $11 \%$ lower than under control condition (100\% FC); however, there was not any significant difference between $50 \% \mathrm{FC}$ and full irrigation. However, evaluation of the total leaf area showed that fertilizer application considerably improved this trait and the lowest leaf area was recorded for plants grown under nofertilizer condition. Nevertheless, the difference between other fertilizer levels was not significant (Table 1). Investigation of cob diameter between different fertilizer treatments revealed that the thinnest cob was related to plant grown under no-fertilizer application. Irrigation levels could not significantly affect this trait (Table 1). Also, ear diameter was considerably affected by the fertilizer as the highest diameter was recorded for plants grown with complete micronutrients nanofertilizers and the thinnest ear was related to no-fertilizer condition. Investigation of ear length revealed that both nutrient and irrigation treatments significantly affected this trait. A comparison of the mean ear length between fertilizers showed that application of complete micronutrients and bulk chemical NPK increased this characteristic up to 28 and 23\%, respectively. Moreover, severe water deficiency (25\% FC) decreased the ear length up to $24 \%$ compared to full irrigated condition. The variance analysis of stem diameter revealed that there were significant main effects of nutrient management and irrigation, as well as significant nutrient management $\times$ irrigation interaction (Table 1). The thickest stems were obtained under full irrigated condition with application of $\mathrm{N}$ biofertilizer which was followed by plants grown under mild water deficiency (50\% FC) with application of nano-chelated $\mathrm{Zn}$. Conversely, the thinnest stems were related to plants with no application of fertilizer under sever water deficiency (25\% FC) and followed by plants grown with $\mathrm{P}$ biofertlizer. An assessment of leaf area showed that this trait substan- tially responded to both nutrient management and irrigation levels and their interaction effect was significant at the 5\% level. The highest leaf area was obtained from plants grown under full irrigation with application of nano-chelated $\mathrm{Zn}$ $\left(3,339 \mathrm{~cm}^{2}\right)$ and in plants under deficit irrigation (50\% FC) with application of nanofertilizers of complete micronutrients $\left(3,161 \mathrm{~cm}^{2}\right)$. However, the lowest leaf area was recorded for plants under sever water deficiency (25\% FC) without fertilizer application $\left(2,424 \mathrm{~cm}^{2}\right)$ which was followed by $\mathrm{N}$ biofertilizer $\left(2,609 \mathrm{~cm}^{2}\right)$. A similar status was observed for chlorophyll content, and there were both a significant main effect and a significant interaction. A comparison of means of combinations of factors showed that the highest chlorophyll content was recorded for plants grown by application of $\mathrm{N}$ biofertilizer and complete micronutrients under full irrigation and 50\% FC, respectively. On the other hand, the lowest chlorophyll content was recorded for plants with no fertilizer or grown by biofertilizers. The important point is that both levels of deficit irrigations significantly reduced the chlorophyll content and this implies that this trait is very sensitive to water deficiency.

A study of the relative water content (RWC) showed that both nutrient management and irrigation significantly affected this parameter, so the application of complete micronutrients could improve RWC value up to $7 \%$ over the control. However, the lowest RWC value between fertilizer treatments was recorded for plants grown by biofertilizers and NPK fertilizer. Although the sever water deficiency could decrease the RWC, interestingly, there was no significant difference between full irrigation and 50\% FC (Table 1).

The result of variance analysis of yield components and grain quality is showed in Table 2. Evaluation of hundred grain weight showed that only irrigation significantly affected this trait, so deficit irrigation noticeably decreased the grain weight and there was no significant difference between the deficit irrigation levels. The number of the kernels per ear was affected by both nutrient management and irrigation, 
Table 2. Comparison of means of yield components, oil and protein percentage in maize (Zea mays L.) as affected by fertilizer and irrigation regimes

\begin{tabular}{|c|c|c|c|c|c|c|c|c|}
\hline Fertilizers (F) & HGW & NKR & NKE & SY & STY & $\mathrm{HI}$ & PRO & OIL \\
\hline Control & $21.25^{\mathrm{a}}$ & $29.66^{c}$ & $528.03^{c}$ & $5431.23^{c}$ & $7041.68^{c}$ & $41.62^{c}$ & $8.76^{c}$ & $5.27^{\mathrm{a}}$ \\
\hline $\mathrm{N}$ biofertilizer & $21.18^{\mathrm{a}}$ & $28.36^{c}$ & $537.32^{\mathrm{bc}}$ & $5393.84^{c}$ & $7874.65^{\mathrm{ab}}$ & $39.12^{\mathrm{d}}$ & $9.04^{\mathrm{bc}}$ & $4.70^{\mathrm{ab}}$ \\
\hline P biofertilizer & $21.29^{\mathrm{a}}$ & $28.61^{\mathrm{c}}$ & $543.31^{\mathrm{bc}}$ & $5426.51^{\mathrm{c}}$ & $7377.74^{\mathrm{bc}}$ & $42.29^{\mathrm{bc}}$ & $8.93^{\mathrm{bc}}$ & $4.98^{\mathrm{ab}}$ \\
\hline Nano-chelated B & $21.22^{\mathrm{a}}$ & $33.67^{b}$ & $556.87^{\mathrm{ab}}$ & $6162.23^{b}$ & $8104.15^{\mathrm{ab}}$ & $43.18^{\mathrm{bc}}$ & $9.90^{\mathrm{ab}}$ & $4.50^{\mathrm{b}}$ \\
\hline Nano-chelated Zn & $21.38^{\mathrm{a}}$ & $34.17^{\mathrm{ab}}$ & $571.48^{\mathrm{a}}$ & $6367.93^{\mathrm{ab}}$ & $8040.33^{\mathrm{ab}}$ & $43.91^{\mathrm{b}}$ & $10.77^{\mathrm{a}}$ & $4.81^{\mathrm{ab}}$ \\
\hline $\begin{array}{c}\text { Complete nanoferti- } \\
\text { lizer }\end{array}$ & $21.61^{\mathrm{a}}$ & $37.88^{a}$ & $578.46^{\mathrm{a}}$ & $6624.66^{\mathrm{a}}$ & $8122.24^{\mathrm{ab}}$ & $46.07^{\mathrm{a}}$ & $9.45^{\mathrm{bc}}$ & $4.87^{\mathrm{ab}}$ \\
\hline Chemical NPK & $20.98^{a}$ & $31.91^{b c}$ & $534.58^{\mathrm{bc}}$ & $5061.21^{\mathrm{c}}$ & $8195.51^{\mathrm{a}}$ & $37.92^{\mathrm{d}}$ & $10.22^{\mathrm{ab}}$ & $4.45^{\mathrm{b}}$ \\
\hline \multicolumn{9}{|c|}{ Irrigation (I) } \\
\hline $100 \% \mathrm{FC}$ & $22.69^{a}$ & $35.91^{\mathrm{a}}$ & $601.92^{\mathrm{a}}$ & $6110.05^{\mathrm{a}}$ & $8421.76^{\mathrm{a}}$ & $40.72^{\mathrm{b}}$ & $9.01^{\mathrm{b}}$ & $5.23^{\mathrm{a}}$ \\
\hline $50 \% \mathrm{FC}$ & $20.95^{\mathrm{b}}$ & $32.42^{\mathrm{a}}$ & $556.91^{\mathrm{b}}$ & $5821.75^{\mathrm{a}}$ & $7730.21^{\mathrm{ab}}$ & $42.80^{\mathrm{a}}$ & $9.45^{\mathrm{ab}}$ & $4.79^{\mathrm{ab}}$ \\
\hline $25 \% \mathrm{FC}$ & $20.17^{\mathrm{b}}$ & $27.79^{b}$ & $491.20^{c}$ & $5397.18^{\mathrm{b}}$ & $7315.09^{b}$ & $42.52^{\mathrm{a}}$ & $10.33^{\mathrm{a}}$ & $4.38^{\mathrm{b}}$ \\
\hline LSD at $p \leq 0.05$ & 1.42 & 3.93 & 22.90 & 419.91 & 754.33 & 1.69 & 1.29 & 0.61 \\
\hline \multicolumn{9}{|c|}{ Significance level } \\
\hline $\mathrm{F}$ & NS & $* *$ & $* *$ & $* *$ & $* *$ & $* *$ & $* *$ & $* *$ \\
\hline $\mathrm{I}$ & * & $* *$ & $* *$ & * & $* *$ & $* *$ & $* *$ & $* *$ \\
\hline $\mathrm{F} \times \mathrm{I}$ & NS & $* *$ & * & $* *$ & NS & $* *$ & NS & NS \\
\hline $\mathrm{CV} \%$ & 4.05 & 5.695 & 12.52 & 17.22 & 5.84 & 2.44 & 8.14 & 7.79 \\
\hline
\end{tabular}

$\mathrm{HGW}=$ hundred grain weight $(\mathrm{g}), \mathrm{NKR}=$ number of the kernels per row, $\mathrm{NKE}=$ number of the kernels per ear, SY = seed yield $\left(\mathrm{kg} \mathrm{ha}^{-1}\right)$, STY = straw yield $\left(\mathrm{kg} \mathrm{ha}^{-1}\right), \mathrm{HI}=$ harvest index $(\%), \mathrm{PRO}=$ protein percentage of seed, $\mathrm{OIL}=$ oil percentage of seed. Mean values of the same category followed by different letters are significant at $p \leq 0.05$ level.

also interaction effect of nutrient management and irrigation statistically was significant at $1 \%$ probability level. The greatest number of kernels per ear was recorded in plants grown by $\mathrm{N}$ biofertilizer under full irrigation and in plants grown by complete micronutrients under $50 \%$ FC, while the lowest number of the kernels per ear was related to boron application under $50 \%$ FC and $\mathrm{N}$ biofertlizer application under sever water deficiency. A similar trend was recorded for the number of the kernels per row, and the highest and lowest value was recorded for plants grown by $\mathrm{N}$ biofertilizer, nano-chelated $\mathrm{Zn}$, and complete micronutrient under full irrigation and $25 \% \mathrm{FC}$, respectively. However, regarding comparison of kernel number per row among the irrigation levels it was interesting to note that there was not any significant difference between full irrigation and 50\% FC (Table 2).
The variance analysis for grain yield revealed that the effect of both main factors of nutrient management and irrigation and their interaction effect was significant. The highest grain yield was obtained under full irrigation and 50\% FC and in plants which received complete micronutrients and nano-chelated $\mathrm{Zn}$. However, the lowest grain yield was recorded in plants with nofertilizer application or biofertilizer inoculation under 25\% FC. Also, a comparison of means of grain yield between irrigation levels indicated that deficit irrigation up to $50 \%$ FC had no significant effect on this fundamental trait.

However, a comparison of the means of straw yield among the fertilizer levels showed that the highest straw yield is obtained by application of NPK bulk fertilizer and followed by complete micronutrient, nano-chelated $\mathrm{Zn}$, and nano-chelated B, respectively. Irrigation 
up to $25 \%$ FC resulted in $14 \%$ decrease of straw yield in comparison with irrigation, whereas there was not a significant difference between the 50\% FC and full irrigation. The significant main effect of nutrient management $(F)$ and irrigation (I) and significant $\mathrm{F} \times \mathrm{I}$ interaction were obtained for the harvest index (Table 2). The lowest value of the harvest index was recorded for plants that received the $\mathrm{P}$ biofertilizer and nano-chelated $\mathrm{B}$ under sever water deficiency (25\% FC), while the highest amount was accounted for the plants grown with NPK and nano-chelated $\mathrm{Zn}$ under 50\% FC. Plants under deficient irrigation showed a higher harvest index value compared to the full irrigation; it seems that water deficiency could improve photoassimilate distribution in plants and positively affected source-sink relationships.

Investigation of the grain quality components (oil and protein) also showed that severe water deficiency $(25 \%$ FC) decreased the oil content by $17 \%$ compared to full irrigation condition, whereas increased protein content by
$14 \%$ over the well irrigated situation (Table 2). Surprisingly, the highest oil percentage was recorded in plants grown without fertilizer application. These results therefore need to be interpreted with caution. However, the application of nano-chelated $\mathrm{Zn}$, chemical bulk NPK, and complete micronutrients resulted in the highest grain protein content in comparison with other treatments.

Regarding the lack of a significant difference between full irrigation and deficit irrigation up to $50 \%$ FC for most of investigated traits, the principal component analysis (PCA) was applied to identify the traits that were the main source of the variability and to illustrate the relationship among different morphophysiological traits under deficit irrigation (50\% FC). Figure 2 displays a biplot in the dimension of the first and second PCs. On the plot, two main groups of traits were separated so that for factor 1 there were plant height, cob diameter, chlorophyll content, leaf area per plant, ear diameter, hundred grain weight, and straw

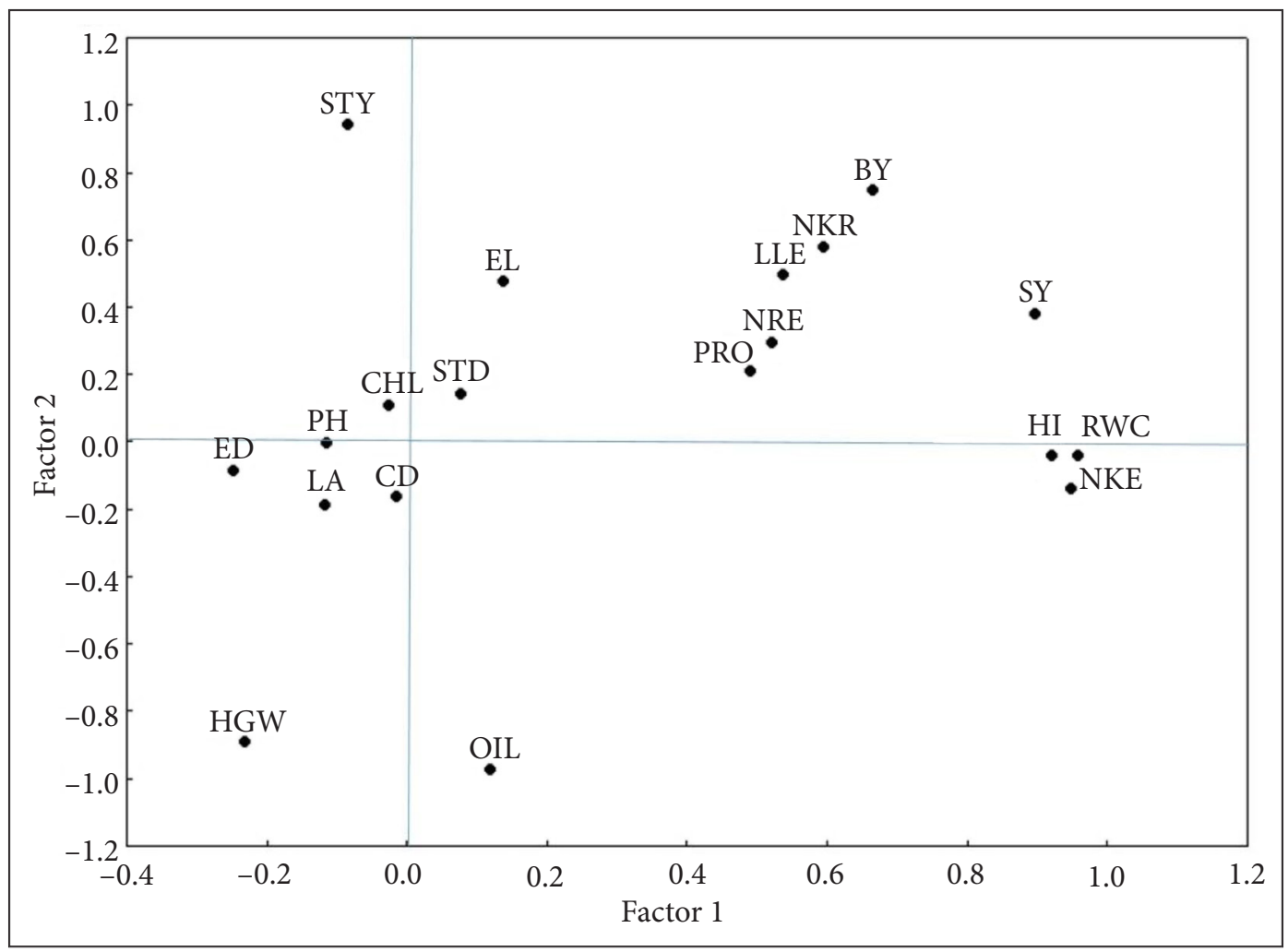

Fig. 2. PCA biplot: spatial distribution of different morphophysiological traits of maize (Zea mays L.) under deficit irrigation (50\% FC) using the first two PCs 
yield. Most of the mentioned traits are related to vegetative growth and biomass production. Besides, factor 2 separated some traits such as relative water content, harvest index, number of the kernels per ear, oil percentage of seed, hundred grain weight, cob diameter, and ear diameter, most of which are yield determinative traits. Evaluations of correlation coefficients among morpho-physiological traits under deficit irrigation are shown in Table 3. There was a positive significant correlation between the leaf length adjacent to ear, hundred grain weight, number of the kernels per row, number of the kernels per ear, relative water content, and biological yield. It is somewhat surprising that under deficit irrigation there was observed a considerable correlation between seed yield and some of the key attributes such as leaf area, chlorophyll content. These results indicate that the relative water content can be used as an acceptable criterion for selection under deficit irrigation.

To better understand the relationships among the measured traits of maize, the relationships are displayed in clusters (Fig. 3). Cluster analysis of traits under deficit irrigation showed that the dendrogram was divided into four clusters. Cluster I consisted of leaf area per plant, oil percentage of seed, hundred grain weight, which drastically decreased by the deficit irrigation and their response to the fertilizers was somewhat different from other traits and this was evident for oil percentage. Cluster II contained the ear diameter, chlorophyll content, ear length, leaf length adjacent to ear, and straw yield, most of which are vegetative components and can indirectly improve grain yield by providing photoassimilates and biomass production. Cluster III contained the relative water content, protein percentage of seed, number of the kernels per ear, number of the kernels per row, harvest index,

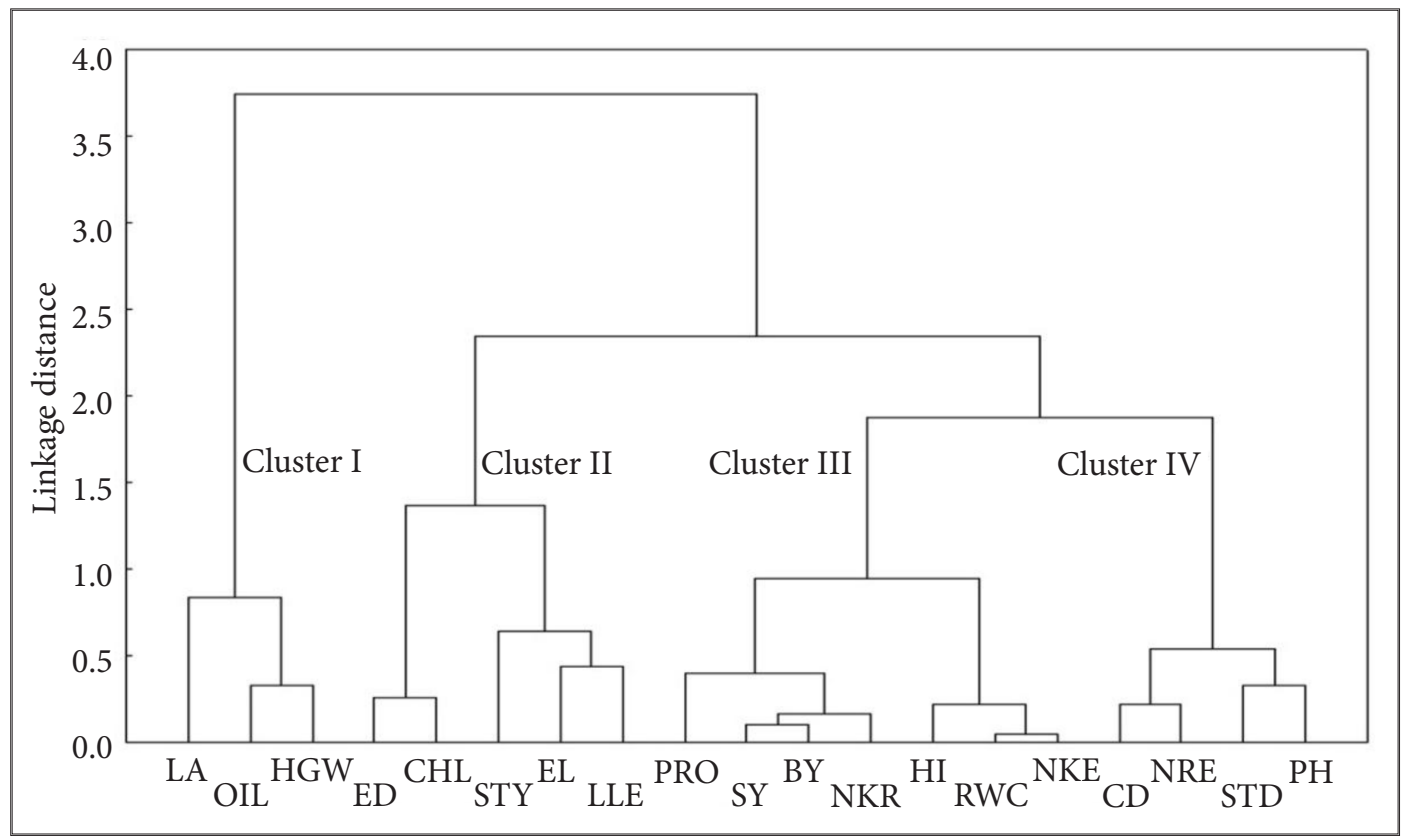

Fig. 3. Cluster analysis of agronomic and moropho-physiological traits in Zea mays grown under irrigation up to 50\% FC. Abbreviations: $\mathrm{PH}=$ plant height, LLE = leaf length adjacent to ear, $\mathrm{HGW}=$ hundred grain weight, NKE = number of the kernels per ear, NKR = number of the kernels per row, $\mathrm{NRE}=$ number of the rows per kernel $(\%), \mathrm{CHL}=$ chlorophyll content, $\mathrm{CD}=$ cob diameter, $\mathrm{ED}=$ ear diameter, $\mathrm{EL}=$ ear length, $\mathrm{RWC}=$ relative water content, $\mathrm{STD}=$ stem diameter, LA = leaf area per plant, BY = biological yield, STY = straw yield, SY = seed yield, HI = harvest index, $\mathrm{PRO}=$ protein percentage of seed, $\mathrm{OIL}=$ oil percentage of seed 


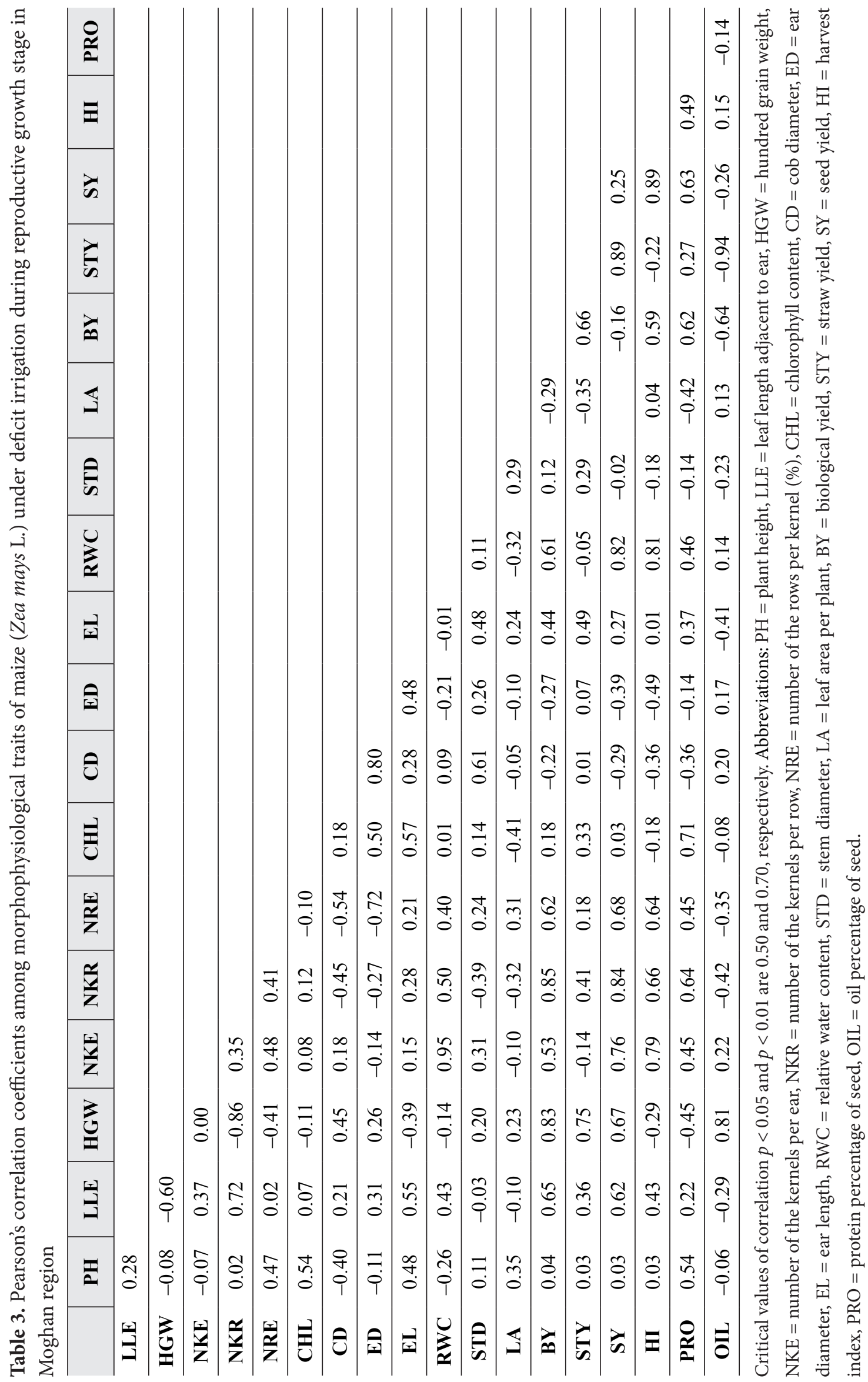


and seed yield. This cluster includes the key yield component (number of grains per ear) and some of the attributes that have a high correlation with the grain yield. This cluster can be considered the most important traits for maize investigation. Cluster IV contained the cob diameter, number of the rows per ear, plant height, and stem diameter, which are the vegetative traits and can indirectly affect grain yield.

\section{DISCUSSION}

Soil nutrients similar to all agricultural inputs necessitate to be managed appropriately to meet the fertility requirements of maize without adversely affecting the environmental aspects. The results of evaluating the fertilizers' effects on growth and yield components of maize showed that nano-chelated micronutrients more impressively improved plant performance in comparison with other investigated fertilizers. The findings of the current study are consistent with those of Janmohammadi (2015) who found that the best performance of safflower in a semiarid region was obtained by foliar application of manganese chelate and zinc sulphate. Although biofertilizers, especially nitrogen biofertilizer, in desirable moisture condition could significantly boost performance compared to the control, their benefits and efficiency were not satisfactory under deficit irrigation. However, our findings differ from results of Ehteshami et al. (2007) who found that maize qualitative and quantitative characteristics were significantly increased by phosphate-solution microorganisms; also, phosphorus solution microorganisms increased the growth and resistance of plants in water deficit conditions. It seems that the efficiency of biofertilizers is substantially affected by strains of bacteria, soil physicochemical properties, climatic condition, soil moisture content, and agronomical operations. This finding confirms the finding of Ryan et al. (2012), which preliminary suggests that in semi-arid regions, especially in areas faced with water shortages, application of solely biofertilizers cannot be an eligible nutrient management option. With regard to the particular climatic conditions and soil properties of semi-arid areas it seems that integrated nutrient management strategies involving chemical fertilizers, organic manures, cereal-legume intercropping, crop residues and biofertilizers are the only viable means of bridging the gap between nutrient requirement and supply to improve agricultural production (Gruhn et al., 200; Zougmoré et al., 2014).

Although macronutrients supplied in the form of traditional NPK fertilizers could improve growth compared with control, the effect of nano-chelated micronutrients was much more impressive. Generally, micronutrient deficiency is a common problem for crop production in semi-arid areas. This is partly due to the conditions of semi-arid areas, where major constraints on the uptake of micronutrients by roots are low soil moisture, soil alkalinity and nutrient depleted and degraded soils. Among the applied nano-chelated micronutrients, the positive effect of $\mathrm{Zn}$ on growth and yield of maize was more prominent. Zinc is an indispensable micronutrient and plays a significant role as a structural constituent or regulatory cofactor of a wide range of different enzymes and proteins in many important biochemical pathways (Hänsch, Mendel, 2009). Furthermore, Zn application can show a synergistic influence on the uptake of other micronutrient cations at the flowering stage of the crop (Suresh et al., 2013). Notwithstanding the limited studies on nanofertilizers, it appears that these fertilizers with slow release of elements greatly increase the chance of nutrient absorption and minimize losses to the environment. Nano-chelated fertilizers due to their small size can easily be absorbed through the foliage, and eventually these properties may improve the efficiency of plant nutrients under water shortage condition and nanofertilizers can be excellent alternatives to soluble fertilizers. It is expected that by the application of nanotechnology in various fields of agriculture the second green revolution can be accelerated. Nevertheless, our results point out that in semi-arid Mediterranean regions at the same time, every effort should be made to improve the availability and use of both macronutrients and micronutrients.

Moreover, results of the present study revealed that levels of deficit irrigation significantly affected plant performance. For most of 
the evaluated traits, a significant difference between full irrigation and deficit irrigation up to $50 \% \mathrm{FC}$ was not observed. The findings of the current study are consistent with those of Abedinpour and Sarangi (2013) and Norwood (2000) who found that for corn, deficit irrigation combined with accurate fertility can be a suitable water management strategy in semiarid regions where groundwater resources are declining. However, in order to ensure successful deficit irrigation, it is necessary to detect the critical levels of deficit irrigation and recognition of proper irrigation scheduling, so the result of this study showed that irrigation up 25\% FC significantly reduced the growth and yield. While most studies were able to demonstrate the benefits of deficit irrigation, Payero et al. (2006) suggested that deficit irrigation for corn might not be a beneficial strategy in semi-arid areas with low rainfall. It appears that critical level of deficit irrigation is greatly influenced by environmental conditions. Totally, our findings indicated that mild deficit irrigation during the reproductive growth stage in maize with application of nano-chelated micronutrients would be efficient management for maximizing water use efficiency in semi-arid regions.

\section{CONCLUSIONS}

In this study, to gain a better understanding about the efficiency of biological and nanofertilizers under various moisture levels, deficit irrigation ( 25 and $50 \%$ FC) was applied during the reproductive growth stage. Findings showed that although the utilization of biological fertilizers increased growth and some of the yield components under well irrigated condition, they failed to maintain their superiority under deficit irrigation. Our results revealed that a maize hybrid (704 single-cross) is well suited for rational deficit irrigation applied during the reproductive growth stages in northwest Iran. The fundamental aim of the irrigation deficit technique is to increase water use efficiency with reducing the volume of water at each irrigation level. In addition, our results indicate that application of bulk NPK, nano-chelated Zn and nanofertilizers of complete mironutients under mild deficit irrigation (50\% FC) could significantly improve plant performance. Although in this study the improving effect of nano-chelated micronutrients on gain yield was more prominent than that of other fertilizers, these fertilizers are new and it will be necessary to extend these data sets to other crops and cultivars and to other soils to achieve precise and advisable results. The relationships between traits showed that relative water content, number of the kernels per ear, and protein percentage had a high correlation with grain yield and can be considered selection criteria under deficit irrigation. The absence of correlation between grain yield and some investigated traits might result from the fact that the relationship between traits under deficit irrigation is partly different from well irrigated condition. In conclusion, with increasing pressure on limited water resources and growing water shortage, the need for application of deficit irrigation will be more sensible, especially in arid and semi-arid regions. This work may provide guidelines for utilization of deficit irrigation. Before implementing this practice, the farmers need to be thoroughly informed about intensity and duration of deficit irrigation which are strongly dictated by climatic conditions and water availability.

\section{ACKNOWLEDGEMENTS}

This research was supported by a grant-in-aid for scientific research from the University of Maragheh and funded by the Ministry of Science, Research and Technology, Iran. We are grateful to Mr. Mazani for providing nanofertilizers as representative of Sepehr Parmis Company (representative in Tabriz). The authors are thankful to Dr. Mojtaba Amini for critically reading the manuscript and making useful suggestions about nanomaterials.

Received 9 March 2015 Accepted 22 June 2016 


\section{References}

1. Abedinpour M, Sarangi A. Deficit irrigation and nitrogen effects on maize growth in semiarid environment. World Appl Sci J. 2013; 21(11): 1687-92.

2. Bhardwaj D, Ansari MW, Sahoo RK, Tuteja N. Biofertilizers function as key player in sustainable agriculture by improving soil fertility, plant tolerance and crop productivity. Microbial Cell Factories. 2014; 13(1): 66.

3. Chen J. The combined use of chemical and organic fertilizers and/or biofertilizer for crop growth and soil fertility. In: International Workshop on Sustained Management of the SoilRhizosphere System for Efficient Crop Production and Fertilizer Use. Land Development Department Bangkok, Thailand. 2006; 16: 20.

4. DeRosa MC, Monreal C, Schnitzer M, Walsh R, Sultan Y. Nanotechnology in fertilizers. Nat Nanotechnol. 2010; 5(2): 91-1.

5. Dobermann A, Cassman KG. Plant nutrient management for enhanced productivity in intensive grain production systems of the United States and Asia. In: Progress in Plant Nutrition: Plenary Lectures of the XIV International Plant Nutrition Colloquium. Netherlands: Springer; 2002. p. 153-175.

6. Ehteshami SMR, Aghaalikhani M, Khavazi K, Chaichi MR. Effect of phosphate solubilizing microorganisms on quantitative and qualitative characteristics of maize (Zea mays L.) under water deficit stress. Pak J Biol Sci. 2007; 10(20): 3585-91.

7. FAO. Statistical Yearbook 2013: World Food and Agriculture. Food and Agriculture Organization of the United Nations. Rome; 2013. p. 289.

8. FAO (1998). Management of nutrients and water in rainfed arid and semi-arid areas. Proceedings of a Consultants Meeting. Joint FAO/ IAEA Division of Nuclear Techniques in Food and Agriculture Vienna (Austria); 1998.

9. Fereres E, Soriano MA. Deficit irrigation for reducing agricultural water use. J Exp Bot. 2007; 58(2): 147-59.
10. Galavi M, Yosefi K, Ramrodi M, Mousavi SR. Effect of bio-phosphate and chemical phosphorus fertilizer accompanied with foliar application of micronutrients on yield, quality and phosphorus and zinc concentration of maize. J Agr Sci. 2011; 3(4): 22.

11. Geerts S, Raes D. Deficit irrigation as an on-farm strategy to maximize crop water productivity in dry areas. Agric Water Man. 2009; 96(9): 1275-84.

12. Golzarfar M, Shirani Rad AH, Delkhosh B, Bitarafan Z. Safflower (Carthamus tinctorius L.) response to different nitrogen and phosphorus fertilizer rates in two planting seasons. Žemdirbystė (Agriculture). 2012; 99(2): 159-66.

13. Gruhn P, Goletti F, Yudelman M. Integrated nutrient management, soil fertility, and sustainable agriculture: Current issues and future challenges. Int Food Policy Res Inst. 2000 .

14. Hänsch R, Mendel RR. Physiological functions of mineral micronutrients ( $\mathrm{Cu}, \mathrm{Zn}, \mathrm{Mn}$, $\mathrm{Fe}, \mathrm{Ni}, \mathrm{Mo}, \mathrm{B}, \mathrm{Cl})$. Current Opinion in Plant Biol. 2009; 12(3): 259-66.

15. Hoekstra TW, Shachak M. Arid lands management: toward ecological sustainability. University of Illinois Press; 1999.

16. Janmohammadi M. Evaluation of the impact of chemical and biological fertiliser application on agronomical traits of safflower (Carthamus tinctorius L.). In: Proceedings of the Latvian Academy of Sciences, Section B; 2015. vol. 69(6). p. 20-4.

17. Janmohammadi M, Javanmard A, Sabaghnia $\mathrm{N}$. Influences of micro-nutrients (zinc and iron) and bio-fertilizer on yield and yield components of chickpea (Cicer arietinum L.) cultivars. Agriculture \& Forestry. 2012; 57(3): 53-66.

18. Marschner H. Marschner's mineral nutrition of higher plants. Marschner P, editor. Academic press; 2012. $672 \mathrm{p}$.

19. Morteza E, Moaveni P, Farahani HA, Kiyani M. Study of photosynthetic pigments changes of 
maize (Zea mays L.) under nano Tio2 spraying at various growth stages. SpringerPlus. 2013; 2(1): $1-5$.

20. Norwood CA. Water use and yield of limitedirrigated and dryland corn. Soil Sci Soc Am J. 2000; 64(1): 365-70.

21. Payero JO, Melvin SR, Irmak S, Tarkalson D. Yield response of corn to deficit irrigation in a semiarid climate. Agr Water Man. 2006; 84(1): 101-12.

22. Ryan J, Sommer R, Ibrikci H. Fertilizer best management practices: A perspective from the dryland West Asia-North Africa region. J Agron Crop Sci. 2012; 198(1): 57-67.

23. Sahrawat KL, Wani SP. Nutrient deficiencies and their management in soils of the semiarid tropical regions. In: Climate Change and Agriculture. Stadium Press (India) Pvt. Ltd., New Delhi; 2013. p. 73-89.

24. Sekhon BS. Nanotechnology in agri-food production: an overview. Nanotech Sci Appl. 2014: 31-53.

25. Siddiqui $\mathrm{MH}, \mathrm{Al}-$ Whaibi $\mathrm{MH}$, Firoz $\mathrm{M}, \mathrm{Al}-$ Khaishany MY. Role of nanoparticles in plants. In: Nanotechnology and Plant Sciences. Springer International Publishing; 2015. p. 19-35.

26. Suresh G, Murthy IYN, Sudhakara Babu SN, Varaprasad KS. An overview of Zn use and its management in oilseed crops. J SAT Agr Res. 2013; 11: 1-11.

27. Zougmoré R, Jalloh A, Tioro A. Climate-smart soil water and nutrient management options in semiarid West Africa: a review of evidence and analysis of stone bunds and zaï techniques. Agr Food Sec. 2014; 3(1): 16.
Mohsen Janmohammadi, Azra Navid, Asghar Ebadi Segherloo, Naser Sabaghnia

\section{NANO CHELATINIŲ MIKROELEMENTŲ IR BIOLOGINIŲ TRĄŠŲ POVEIKIS AUGIMO RODIKLIAMS IR KUKURŪZŲ DERLIUI DEFICITINE்MIS DRE்KINIMO SĄLYGOMIS}

\section{Santrauka}

Darni augalininkyste, reikalinga pusiau sausringose teritorijose, bus pasiekta naudojant gamybos priemones, pritaikytas unikalioms kiekvieno rajono sąlygoms. Siekiant ištirti įvairių trąšų poveikị kukurūzų (S.C 704 hibridas) augimui skirtingomis drèkinimo sąlygomis, buvo atliktas lauko eksperimentas šiaurès vakarų Irane (Moghan). Tyrimo metu trys drèkinimo lygiai (iki 100\%, 50 \% ir $\sim 25 \%$ lauko talpos) buvo taikyti nuo reprodukcinio laikotarpio pradžios. Tręšimo sąlygos: kontrolè (nenaudotos trąšos), $\mathrm{N}$ biotrąšos, $\mathrm{P}$ biotrąšos, $\mathrm{B}$ nano chelatiniai junginiai, $\mathrm{Zn}$ nano chelatiniai junginiai, pilnas nano trąšų kompleksas, birios NPK trąšos. Morfofiziologinių savybių (lapų plotis, ilgis ir skersmuo, santykinis vandens ir chlorofilo kiekis) tyrimas rodo, kad pilnas nano trąšų kompleksas, birios NPK trąšos ir Zn nano chelatiniai junginiai ženkliai jas pagerino, palyginti su kontrole. Panaši buvo grūdų derliaus ir jo komponentų būklè. Remiantis rezultatais, didžiausiu našumu pasižymèjo augalai, kurie buvo tręšti pilnu nano trąšų kompleksu ir kuriems taikytas optimalus arba $\sim 50 \%$ lauko talpos drèkinimo lygis. Deficitinį drèkinimą iki 50 \% lauko talpos galima laikyti tinkama strategija pusiau sausringuose regionuose siekiant sumažinti vandens nuostolius dèl garavimo ir efektyviau panaudoti vandenị.

Raktažodžiai: biotrąšos, nano chelatiniai junginiai, nano trąšos, vandens panaudojimas, derliaus komponentai 